\title{
EMPLOYEE PERFORMANCE REVIEWED FROM KNOWLEDGE MANAGEMENT, ATTITUDE AND TRAINING AT SAHID JAYA HOTEL SOLO
}

\author{
Rizal Fadhilah Syahidin ${ }^{1}$, Sudarwati ${ }^{2}$, Ratna Damayanti ${ }^{3}$ \\ Department of Management, Faculty of Economics \\ Batik Islamic University of Surakarta \\ Email: rsyahidin@gmail.com
}

\begin{abstract}
This study aims to test the influence of Knowledge Management, Attitude and Training on employee performance at Sahid Jaya Hotel Solo. The population in this study was 75 employees. This study used census sampling techniques because the sample studied was the entirety of the existing population or called the census, based on policies during the pandemic, then the employees who attended as many as 45 employees. In this study, researchers took a sample of 45 employees. This research is quantitative research. The data analysis techniques used for this study used multiple liner regression. Based on the results of hypothetical tests, especially the F test, it was found that knowledge management, attitude, and training simultaneously have a positive and significant influence on employee performance. $T$ test results show that Knowledge Management has a positive and significant effect on employee performance, Attitude has no effect on employee performance, training has a positive and significant effect on employee performance.
\end{abstract}

Keywords: Knowledge Management, Attitude, Training, Employee Performance

\section{Introduction}

In the era of globalization many companies are required to be able to maximize better employee performance. Because in the era of globalization companies in Indonesia continue to experience very tight competition so that companies have to increase human resources to face very tight competition. The Company is required to obtain, develop and maintain quality human resources. Human resources have a very important role in the company because one of the determining factors of the success or not of a company in achieving its goals requires the effort of human resources owned. The Company must implement human resource management strategies well for the sake of the company's survival and progress.

The Company strives to develop the performance and standard of living of employees. The role of company management in directing, guiding and creating a healthy industrial climate to the company is to create a stronger and more balanced 
economic structure. (Sinambela, 2012) revealed the performance of employees is very necessary, because with this performance will be known how far the ability of employees in carrying out the duties charged to him.

The success factor of the organization now is to become a learner organization. Learning in the context of Knowledge Management plays a major role, especially in the process of knowledge creation. The knowledge created can then be shared and transferred between employees, groups and the entire organization. Organizations that implement Knowledge Management always encourage learning to take place effectively because the organsasi who learn will always have the ability to face changes. Therefore, learning in the context of knowledge management is very strategic position.

The Company must make human resource empowerment efforts aimed at improving the performance of each individual and of course the company's performance will also improve. Work attitudes are a collection of feelings, beliefs, and thoughts held and organizational, attitudes specific to values and permanent because the way people perceive and work often changes over time.

Effective organizations must be able to find, empower, sustain, and develop people to achieve the results envisioned (Marwansyah, 2012). It can be concluded that the achievement of the company's objectives is largely determined by its human efforts, both in planning, organizing, steering, coordinating and controlling activities. One way to develop the performance of employees in the company is the implementation of a training program in which the program applied is made according to the needs of the company.

Sahid Jaya Hotel Solo is the pioneer of all Sahid Hotels in Indonesia and also a pioneer in the construction of multi-storey hotels in Solo. Sahid Jaya Solo is the perfect hotel for business or a smooth vacation, so in providing services of course requires Sahid Jaya Hotel Solo to always be ready to compete by providing the maximum service possible by utilizing the latest technology. Based on customer feedback in Traveloka online booking application, there are some dissatisfied responses to services and facilities at Sahid Jaya Hotel Solo. This condition requires Sahid Jaya Hotel Solo to implement strategies to improve the quality of human resources by improving the performance of employees in providing maximum service to customers.

Based on these backgrounds, the problem in this study is, how knowledge management, attitude and training affect the performance of sahid jaya hotel employees in Solo. How knowledge management affects employee performance at Sahid Jaya Hotel Solo. How attitude affects employee performance at Sahid Jaya Hotel Solo. How does Training affect Employee Performance at Sahid Jaya Hotel Solo.

\section{Theoretical Foundation}

\section{Employee Performance}

(Torang, 2013), Employee performance can also be determined as a person's ability to perform and also includes opportunities and willingness to do their duties. The meaning 
International Journal of Economics, Business and Accounting Research (IJEBAR)

Peer Reviewed - International Journal

Vol-5, Issue-1, 2021 (IJEBAR)

E-ISSN: 2614-1280 P-ISSN 2622-4771

https://jurnal.stie-aas.ac.id/index.php/IJEBAR

of willingness to do its job means that there is a desire of employees in putting a lot of effort into their work.

\section{Knowledge Management}

(Budiharjo, 2016), the view is that knowledge management is a systematic activity that offers knowledge management in terms of acquisition, use, variety, storage, re-search and development so as to generate new ideas that have an impact on innovation.

\section{Attitude}

(Robbins, 2015), attitude is an evaluative statement, both pleasant and unpleasant, about objects, people or events. Attitude reflects how we feel about something. (Hakim, 2010) attitude is a way of placing or carrying yourself, or a way of feeling, way of thinking, and behavior.

\section{Training}

(Hasibuan, 2009), training is an effort to improve the technical, theoretical, conceptual, and moral abilities of employees in accordance with the needs of the job. (Desssler, 2010), Training is the learning process of basic skills needed by new employees to carry out work.

\section{Framework}

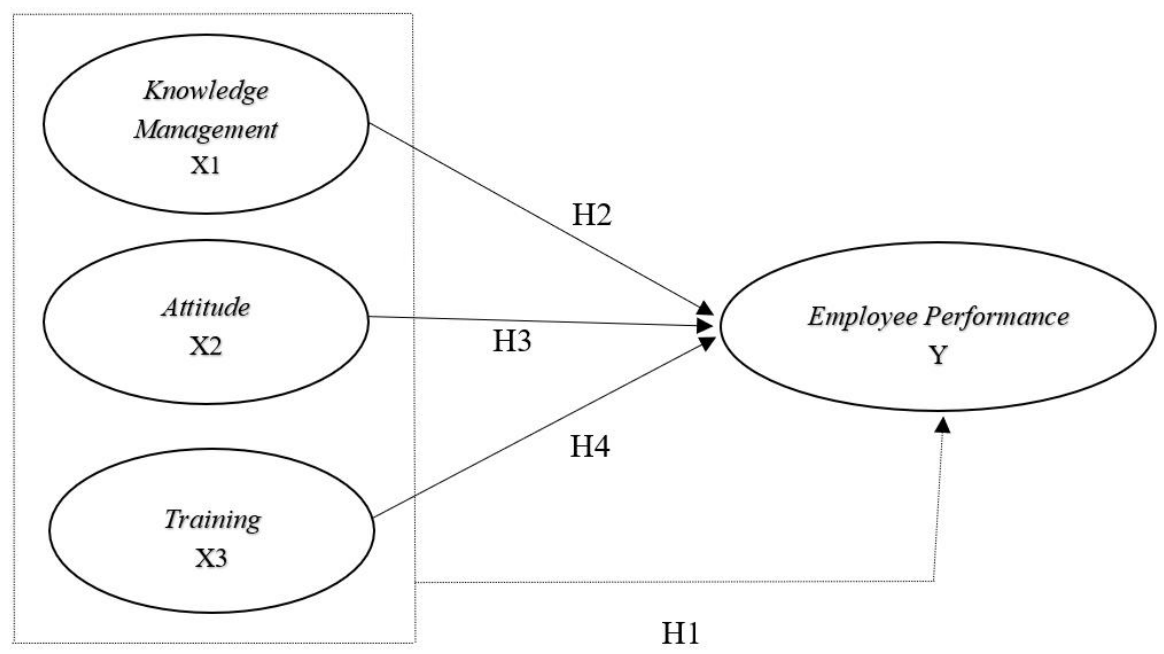

Picture 1.

Framework

Based on the above framework, the hypotheses in this research are as follows, There is a positive and significant influence of knowledge management, attitude, and training on employee performance at Sahid Jaya Hotel Solo. There is a positive and significant influence of knowledge management with the performance of employees at Sahid Jaya Hotel Solo. There is a positive and significant influence on employee 
International Journal of Economics, Business and Accounting Research (IJEBAR)

Peer Reviewed - International Journal

Vol-5, Issue-1, 2021 (IJEBAR)

E-ISSN: 2614-1280 P-ISSN 2622-4771

https://jurnal.stie-aas.ac.id/index.php/IJEBAR

performance at Sahid Jaya Hotel Solo. There is a positive and significant influence of training on employee performance at Sahid Jaya Hotel Solo.

\section{Analysis Methods}

Scope of Research

This type of research is a quantitative method of research to find out the influence of knowledge management, attitude and training on employee performance at Sahid Jaya Hotel Solo.

\section{Types and Data Sources}

This research uses quantitative data, namely data obtained from the number of employees. The data source of this research is data obtained by researchers directly in the place of research or a place that becomes the object of research. This data was obtained from the filling out of questionnaires by respondents.

\section{Population and Research Samples}

This study used census sampling techniques because the sample studied was the entirety of the existing population or called the census, based on policies during the pandemic, then the employees who attended as many as 45 employees. In this study, researchers took a sample of 45 employees.

\section{Data Collection and Data Analysis Methods}

Data collection techniques in this study are observations, interviews, questionnaires that are distributed to respondents. Data analysis uses multiple linear regression analysis techniques with the help of SPSS 15.

\section{Results and Discussion}

\subsection{Result}

\section{Instrument Test}

Validity test

Table.1. Validity Test Results

\begin{tabular}{cccc}
\hline Item & R-count & r-table & Description \\
\hline KK1 & 0,815 & 0,2940 & Valid \\
KK2 & 0,880 & 0,2940 & Valid \\
KK3 & 0,798 & 0,2940 & Valid \\
KK4 & 0,935 & 0,2940 & Valid \\
KK5 & 0,935 & 0,2940 & Valid \\
KM1 & 0,797 & 0,2940 & Valid \\
KM2 & 0,782 & 0,2940 & Valid \\
KM3 & 0,809 & 0,2940 & Valid \\
KM4 & 0,702 & 0,2940 & Valid \\
AT1 & 0,883 & 0,2940 & Valid \\
AT2 & 0,860 & 0,2940 & Valid \\
AT3 & 0,849 & 0,2940 & Valid \\
AT4 & 0,926 & 0,2940 & Valid
\end{tabular}


International Journal of Economics, Business and Accounting Research (IJEBAR)

Peer Reviewed - International Journal

Vol-5, Issue-1, 2021 (IJEBAR)

E-ISSN: 2614-1280 P-ISSN 2622-4771

https://jurnal.stie-aas.ac.id/index.php/IJEBAR

\begin{tabular}{llll} 
AT5 & 0,883 & 0,2940 & Valid \\
TR1 & 0,931 & 0,2940 & Valid \\
TR2 & 0,907 & 0,2940 & Valid \\
TR3 & 0,760 & 0,2940 & Valid \\
TR4 & 0,931 & 0,2940 & Valid \\
\hline
\end{tabular}

Source: Processed Primary Data 2020

Based on the table above, of the 18 questionnaires conducted on 45 employees were declared valid because the rcount on all questions was greater than rtable (rcount > 0.2940).

Reliability Test

Table 2. Reliability Test Results

\begin{tabular}{lccc}
\hline \multicolumn{1}{c}{ Variable } & $\begin{array}{c}\text { Alpha } \\
\text { Coefficient }\end{array}$ & $\begin{array}{c}\text { Nunnaly } \\
\text { Criteria }\end{array}$ & Description \\
\hline $\begin{array}{l}\text { Employee performance }(\mathrm{Y}) \\
\text { Knowledge }\end{array}$ & 0,914 & 0,6 & Reliabel \\
Management $(\mathrm{X} 1)$ & 0,769 & 0,6 & Reliabel \\
Attitude (X2) & 0,925 & 0,6 & Reliabel \\
Training (X3) & 0,897 & 0,6 & Reliabel \\
\hline
\end{tabular}

Source: Processed Primary Data 2020

Based on the reliability test results above shows that the coefficient of reliability (Cronbach Alpha) in the variables knowledge management, attitude, training and Employee Performance can be said to be reliable because $>0.6$ in accordance with nunnaly criteria.

\section{Multiple Linear Regression Analysis}

Table.3. Multiple Linear Regression Analysis results

\begin{tabular}{lccc}
\hline \multicolumn{1}{c}{ Variable } & $\begin{array}{c}\text { Regression } \\
\text { Coefficient }\end{array}$ & t & Sig. \\
\hline Constant & $-5,719$ & & \\
Knowledge Management & 0,577 & 2,103 & 0,042 \\
Attitude & $-0,146$ & $-0,653$ & 0,517 \\
Training & 1,127 & 3,710 & 0,001 \\
\hline Source: Processed Prima
\end{tabular}

Source: Processed Primary Data 2020

Based on the results of the regression analysis, the regression equation is obtained as follows:

$\mathrm{Y}=-5,719+0.577 \mathrm{X} 1-0.146 \mathrm{X} 2+1.127 \mathrm{X} 3+\varepsilon$

Based on the equation above, it can be explained that if $\mathrm{X} 1, \mathrm{X} 2$, and $\mathrm{X} 3$ are equal to zero, then the value of Y (Employee Performance) is - 5,719.

\section{Hypothesis Test}

The hypothesis tests conducted in this study are as follows: 
Coefficient of Determination $\mathrm{R}^{2}$

\begin{tabular}{ccc}
\multicolumn{2}{c}{ Table 4. Coefficient of Determinan $\mathrm{R}^{2}$ Result } \\
\hline $\mathbf{R}$ & $\mathbf{R}^{2}$ & Adjusted $\mathbf{R}^{2}$ \\
\hline 0,765 & 0,585 & 0,554 \\
\hline
\end{tabular}

Source: Processed Primary Data 2020

Based on the results above, adjusted $\mathrm{R}$ square value obtained by 0,554 or $55,4 \%$, meaning the contribution of knowledge management, attitude and training variables as independent variables are able to explain variations in employee performance variable changes as dependent variables of 55,4\%, while the remaining $44,6 \%$ is explained by other variables outside the model.

F Test

Table 5. F.test Result

\begin{tabular}{llccccc}
\hline Model & $\begin{array}{c}\text { Sum of } \\
\text { Square }\end{array}$ & df & $\begin{array}{c}\text { Mean } \\
\text { Square }\end{array}$ & F & Sig. \\
\hline 1 & Regression & 194,681 & 3 & 64,894 & 19,239 & 0,000 \\
& Residual & 138,297 & 41 & 3,373 & & \\
Total & 332,978 & 44 & & & \\
\hline
\end{tabular}

Source: Processed Primary Data 2020

Based on the above results obtained F calculate greater than F table $(19,239>$ 2,833 ), it can be concluded that the variables knowledge management, attitude and training simultaneously affect the performance of employees Sahid Jaya Hotel Solo.

t Test

Table 6. t Test Result

\begin{tabular}{lcccc}
\hline \multicolumn{1}{c}{ Variable } & t count & t table & Sig & Conclusion \\
\hline Knowledge Management & 2,103 & 1,683 & 0,042 & Ha received \\
Attitude & $-0,653$ & 1,683 & 0,517 & Ha rejected \\
Training & 3,710 & 1,683 & 0,001 & Ha received \\
\hline
\end{tabular}

Source: Processed Primary Data 2020

Based on the results of the $t$ test above, the knowledge management and training variables partially positive and significant affect the performance of employees at Sahid Jaya Hotel Solo, while for the attitude variables have no influence on the performance of employees of Sahid Jaya Hotel Solo.

\subsection{Discussion}

The results of multiple linear regression analysis prove that the dimension of service quality, which includes knowledge management, attitude, and training, simultaneously positively affects employee performance. But there are partial 
variables that negatively affect employee performance. knowledge management, attitude, and training had a positive influence on employee performance by $55,4 \%$, while the remaining $44,6 \%$ were influenced by other factors that were not thorough in this study. This means that knowledge management, attitude, and training provided by Sahid Jaya Hotel Solo contribute positively to employee performance.

The hypothetical test results showed that the results of Knowledge Management had an influence on the performance of employees of Sahid Jaya Hotel Solo. This research supports the results of previous research, (Pritania, 2017) where in the study obtained results that knowledge management gives a partial positive and significant influence on the performance of employees PT. Bank Rakyat Indonesia SKK BRI Samarinda City.

The hypothetical test results showed that attitude results had no influence on the performance of sahid jaya hotel employees in Solo. This research supports the results of previous research (Amaral, 2018) where attitude variables do not have a significant influence on employee performance in PT. Adi Satria Abadi.

Hypothetical test results showed that the training results had an influence on the performance of sahid jaya hotel employees in Solo. This research supports the results of previous research, (Safitri, 2019) where in the study obtained results that training has a positive and significant influence on employee performance at PT. Batam.

\section{Conclusion and Suggestions \\ Conclusion}

a. Knowledge management, attitude, and training simultaneously have a positive effect on employee performance at Sahid Jaya Hotel Solo.

b. Knowledge management has a positive and significant effect on employee performance at Sahid Jaya Hotel Solo.

c. Attitude has no effect on employee performance at Sahid Jaya Hotel Solo.

d. Training has a positive and significant effect on the performance of employees at Sahid Jaya Hotel Solo.

\section{Suggestions}

For companies

Knowledge Management that has been done by Sahid Jaya Hotel Solo has been running well with test results that show a significant effect between variable $\mathrm{X}$ and $\mathrm{Y}$. However, it is still necessary to routinely evaluate the superiors on activities and aspects that still feel the need for improvement.

Regarding attitude, Hotel Sahid Jaya Solo should approach employees through their attitude in dealing with employees, then the same thing is done by the employee's attitude towards his co-workers and lastly about the attitude of self done by employees. Attitude is very important for employees towards their work. 
International Journal of Economics, Business and Accounting Research (IJEBAR)

Peer Reviewed - International Journal

Vol-5, Issue-1, 2021 (IJEBAR)

E-ISSN: 2614-1280 P-ISSN 2622-4771

https://jurnal.stie-aas.ac.id/index.php/IJEBAR

In the training variables, for the company is expected to give more attention to the knowledge of employees through the implementation of training and increase the intensity of meetings to increase the knowledge of employees so that the performance is better to be able to provide services to customers that will directly affect the company's performance.

For further researchers, it is recommended to be able to examine other variables to find out how much influence on employee performance on the company.

\section{Reference}

Amaral, Lucelia Maria Da Costa, D. (2018). Analisis Pengaruh Sikap, Pola Pikir dan Mentalitas Terhadap Kinerja Karyawan (Studi Kasus di PT. Adi Satria Abadi. Jurnal Rekavasi, Vol.6 No.2.

Budiharjo, \& Andreas. (2016). A Guide Book Knowledge Management Efektif Berinovasi Meraih Sukses (Cetakan ke). Prasetya Mulya Publishing, Jakarta.

Desssler, G. (2010). Manajemen Sumber Daya Manusia. PT. Indeks.

Hakim, A, R. (2010). Pengaruh Kepribadian, Sikap, dan Kepemimpinan Terhadap Kinerja Kreatif Dalam Organisasi. Fakultas Ekonomi Dan Bisnis. Universitas Diponegoro. Semarang.

Hasibuan, M. S. . (2009). Manajemen Sumber Daya Manusia (cet. 13). Jakarta: PT.Bumi Askara.

Marwansyah. (2012). Manajemen Sumber Daya Manusia. Bandung: Alfabeta.

Pritania, N. D. (2017). Pengaruh Knowledge Management dan Skill Serta Attitude Terhadap Kinerja Karyawan pada PT.Bank Rakyat Indonesia (SKK BRI) Kota Samarinda. Jurnal Penelitian Skripsi Manajemen Fakultas Ekonomi Dan Bisnis, 21.

Robbins, \& Stephen. (2015). Perilaku Organisasi, Edisi Ke16. Salemba Empat, Jakarta.

Safitri, D. E. (2019). Pengaruh Pelatihan Terhadap Kinerja Karyawan. vol.8.

Sinambela, \& Poltak, L. (2012). Kinerja Pegawai. Graha Ilmu Yogyakarta.

Torang, S. (2013). Sumber Daya Manusia. Bandung: Alfabeta. 